\title{
Innovativ formidling af førsteårsstuderende - et design-based research-forløb
}

\section{Ole Eggers Bjælde}

Undervisningsudvikler og specialkonsulent Ole underviser på alle karrieretrin på Aarhus Universitet og udvikler undervisning og bedømmelsesformer i retning af en mere innovativ, effektiv og tidssvarende praksis. Ole har en baggrund som astrofysiker og underviser ligeledes på første år af

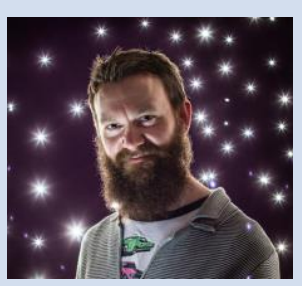
fysikuddannelsen, hvorfra dette forløb kommer.

\section{Rasmus Brøgger Najbjerg}

Gymnasielærer i fysik og kemi

Rasmus blev cand. scient. på Aarhus Universitet sommeren 2016. Det afsluttende speciale var med Ole som vejleder og danner baggrunden for denne unders $\varnothing$ gelse. I dag er Rasmus årsvikar på Kalundborg Gymnasium og HF, hvor han bl.a. stræber efter at skabe alternative tilgange til undervisningen.

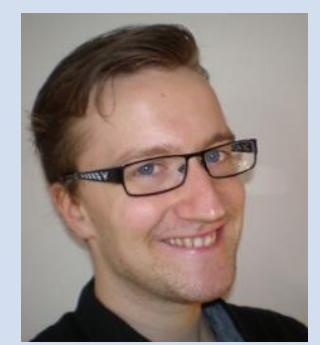




\section{Abstract}

14 videoproduktioner, 4 tegneserier, 3 filmfortællinger, 2 sange, 2 nyhedsindslag, 2 børnebøger, 2 facebook-sider, 1 novelle og 1 toiletrulle var blandt resultaterne, da 112 førsteårsstuderende i det obligatoriske kursus Astrofysik på fysikuddannelsen på Aarhus Universitet blev deltagere i et learning design-forløb, som en del af deres eksamen i kurset. Målet med forløbet var dels at sætte fokus på faglig formidling som en væsentlig kompetence blandt universitetsstuderende, men samtidig også at bringe værdier som kreativitet og innovation i spil.

Forløbet var tilrettelagt efter principperne for design-based research, og publikationen her sætter fokus på intention, implementering, realisering og perspektivering af det underliggende design med henblik på forbedring af designet til fremtidig brug samt på en vurdering af forløbets samlede impact.

Et delmål med publikationen er at give inspiration og vejledning til andre undervisere eller undervisningsudviklere, som ønsker at skabe undervisning, hvor studerende kan arbejde med formidling og kreativitet.

Denne artikel er blevet til på baggrund af specialet i fysik udført af Rasmus Brøgger Najbjerg og flere dele af artiklen er taget direkte fra specialet (Najbjerg, 2016).

\section{Introduktion}

Forskningsarbejdet beskrevet i denne artikel er udført som design-based research, hvilket i denne kontekst betyder, at

"ny viden genereres gennem processer, som samtidig udvikler, afprøver og forbedrer et design"

(Brun, Gynther \& Christensen, 2012).

Således er artiklens primære forskningsspørgsmål: Hvordan er sammenhæng mellem intention, implementering og realisering for det underliggende læringsdesign (Dalziel et al., 2013; Conole 2013)? Det anvendte design i dette forløb er afbilledet og beskrevet i Figur 1 i afsnittet om implementering og er skabt ud fra følgende fire principper (Cobb, Confrey, diSessa, Lehrer, Schauble, 2003; Amiel \& Reeves, 2008; Brun et al., 2012)

- Det intervenerer i undervisningspraksis

- Det er nytænkende/innovativt og forbedrer en undervisningspraksis

- Det bygger på solide teoretiske, didaktiske begrundelser

- Det forbedres iterativt 
Vi vil her kort uddybe hver af de fire punkter i konteksten for dette forløb.

Designet intervenerer i undervisningspraksis

Designet er udviklet til en formidlingsaktivitet, hvor 147

førsteårsstuderende på det obligatoriske kursus Astrofysik på

fysikuddannelsen på Aarhus Universitet, blev stillet en opgave om at lave en produktion, som formidler Universets udvikling fra Big Bang til idag. Formatet for produktionen var frit, og produktionen bidrog med 10\% af den samlede eksamenskarakter i kurset. Bedømmelseskriterier var kendt af studerende på forhånd. For at imødekomme studerendes tidsforbrug, blev anden undervisning i kurset kraftigt neddroslet i løbet af de to uger, hvor forløbet fandt sted. Alt dette skal ses som en modvægt til mere traditionelle undervisningsformer - i særdeleshed forelæsningen - som praktiseres på de fleste universiteter. I designet her overtager studerende således formidlingsrollen fra forelæseren.

Designet er nytænkende/innovativt og forbedrer en undervisningspraksis

Der var flere formål med forløbet: At sætte fokus på studerendes faglige formidling, at nytænke studerendes brug af medier og informationssøgning, at eksperimentere med eksamensformater samt at bringe kreativitet ind som et selvstændigt mål med undervisningen.

Såvel formidling som informationssøgning er kompetencer, som er skrevet direkte ind i studieordningen for bacheloruddannelsen i fysik. Samtidig er det kompetencer, som kan være udfordrende at passe ind i et kort undervisningsforløb, som kurset Astrofysik repræsenterer.

Eksamen er en meget kraftig motivationsfaktor for studerende, hvilket gør det til et oplagt sted at tænke læring ind. Ideelt er eksamen ikke blot en afprøvning af studerendes viden og kunnen, men en integreret del af læringsprocessen. Assessment for learning ikke assessment of learning (Carless, 2015). I eksamensbekendtgørelsen står der direkte, at uddannelserne

"skal indeholde en variation af prøveformer, der skal afspejle undervisningens indhold og arbejdsformer"

(Eksamensbekendtgørelsen, 2016)

Forløbet her er et lille eksempel på, hvordan man kan nytænke eksamensformatet.

Kreativitet er, på linje med formidling, en værdsat kompetence i mange sammenhænge. Det er dog også en kompetence, som kan være svær at italesætte i undervisning og i særdeleshed at træne i undervisningsforløb.

Designet til dette forløb er skabt for at imødekomme disse udfordringer. 
Designet bygger på solide teoretiske, didaktiske begrundelser

Det teoretiske fundament for designet er i udstrakt grad socialkonstruktivisme samt undervisningstilgangene Inquiry-based learning og Learning by teaching. Det teoretiske fundament vil blive yderligere beskrevet under afsnittet Intention.

\section{Designet forbedres iterativt}

Denne artikel repræsenterer en refleksion over første cyklus af en iterativ forbedringsproces. Således forbereder arbejdet bag denne artikel næste formidlingsprojekt, som vil finde sted i efterår/vinter 2016. Der indhentes både kvalitativ og kvantitativ empiri, som kan informere beslutninger om forbedringer og ændringer af det valgte design.

Desuden er det et mål for publikationen her, at den kan fungere som inspiration og metodeanvisning til undervisere og undervisningsudviklere, som ønsker at nytænke undervisning i retning af formidling og kreativitet.

Den resterende del af artiklen er opdelt i sektionerne Intention, Implementering, Realisering, Perspektivering og Konklusion

\section{Intention}

Formidling, informationssøgning og kreativitet er ord og færdigheder, som vil være attraktive at kunne skrive i et CV for de fleste studerende. Samtidig er det ord og færdigheder, som harmonerer med et fokusområde på danske universiteter; at uddanne bachelorer og kandidater med en palette af kompetencer og viden, som gør dem parate til jobs som forskere, undervisere, udviklere, projektledere, osv. Employable.

(Uddannelsesbekendtgørelsen, 2016)

Formidling er ligeledes en færdighed, som er nævnt i kvalifikationsrammen og i studieordningen for såvel bachelor- som kandidatuddannelsen generelt. Det er en kompetence, som er så væsentlig, at den må trænes mange gange i løbet af et samlet studium.

Formidling i form af undervisning udført af studerende kan desuden være en meget stærkt metode til at lære et fagområde på. Læringsstrategien betegnes bl.a. Lernen durch Lehren/Learning by Teaching (Martin \& Kelchner, 1998; Martin, 2004) og har til hensigt at involvere og motivere studerende til at opnå en dybere forståelse af et emne, sådan at de kan forklare deres tilegnede viden videre. Metoden indeholder en forberedelsesfase, hvor de studerende søger og udvælger information med henblik på videreformidling. Desuden indeholder den en forklaringsfase, hvor de studerende integrerer den nye viden blandt forudgående viden for at skabe sammenhængende forklaringer. Metoden kan bruges på forskellige niveauer, men i denne case tages udgangspunkt i formidling 
udført af førsteårsstuderende på universitetet rettet mod en selvvalgt målgruppe.

Kreativitet kan være et vanskeligt begreb at håndtere for studerende pga. forskellige opfattelser af, hvad ordet dækker over (Drapeau, 2014). Den Danske Ordbogs definition på kreativitet er:

"Evne til at få nye idéer og udtrykke dem (på en fantasifuld eller kunstnerisk måde)"

(Det Danske Sprog- og Litteraturselskab, 2016).

I forsknings- og udviklingsprocesser er evnen til at få nye ideer og udtrykke dem helt central, hvilket understreger vigtigheden af kreativitet som kompetence. Ganske vist er kreativitet ikke en kompetence, som bekrives direkte i kvalifikationsramme eller studieordning, men at inddrage kreativitet i undervisningen kan have andre bidrag end at opnå kreativitet. Kreativitet kan således gøre undervisning mere spændende ved fx at ændre pensum til mere tankefulde udfordringer, ved at gøre bedømmelse mere autentisk eller ved at give undervisere og studerende nye roller (Thomson \& Sefton-Green, 2011).

Formidling, informationssøgning og kreativitet er færdigheder som kan opøves godt, når undervisningen tilrettelægges som undersøgelsesbaseret undervisning også kaldet inquiry-based learning, hvor undervisningen tager karakter som forskningsarbejde (Badley, 2002; Healey, 2005; Rienecker, Jørgensen, Dolin \& Ingerslev, 2013). Her er ansvaret for at styre og organisere processen ofte overladt til de studerende, og det er derfor en læringsstrategi som sætter krav til studerendes autonomi, men som samtidig kan være med til at øge studerendes motivation og self efficacy (Bandura, 1977; Semke \& Wiben, 2016). Samtidig giver metoden plads til at tænke divergent, da underviseren i højere grad slipper tøjlerne. På den måde bliver der bedre plads til kreativitet i studerendes arbejdsproces.

Studerendes arbejdsproces kan i et inquiry-based learning-forløb i grove træk beskrives ved fem faser, hvilket kendes som 5E-modellen (Bybee, 2014)

- Engage: Den indledende fase, hvor målet er, at de studerende engageres og får interesse og nysgerrighed for et emne eller en problemstilling. Her aktiveres forudgående viden om emnet.

- Explore: De studerende arbejder sammen på at udforske problemstillingen. De identificerer og udvikler koncepter og processer.

- Explain: De studerende kommunikerer definitioner og koncepter med deres egne ord og opmuntres til at argumentere og bruge evidens i deres forklaring. 
- Elaborate: Dette er en uddybende fase, hvor den opnåede viden anvendes og raffineres. De studerende udfordres til reflektere over implikationer og sammenhænge.

- Evaluate: Denne fase indeholder en dobbelthed, da underviseren evaluerer de studerende, og de studerende vurderer deres eget udbytte og forståelse efter forløbet.

5E-modellen er skabt ud fra en konstruktivistisk læringstilgang, hvor studerende bygger ny viden ovenpå eksisterende viden i overgangen mellem de forskellige faser. 5E-modellen er udvalgt, da formidlingsopgavens tre hovedformål faglig formidling, informationssøgning og kreativitet er indbygget i modellen på forhånd. 5E-modellen har således lagt grundlaget for hvordan formidlingsopgaven er blevet implementeret $\mathrm{i}$ undervisningen via det anvendte læringsdesign, og denne artikel undersøger bl.a. hvorvidt alle faser blev realiseret i de studerendes arbejde.

\section{Implementering}

Kurset Astrofysik er et kursus på 5 ECTS, der er inkluderet i den obligatoriske førsteårsprøve for bacheloruddannelsen i fysik på Aarhus Universitet. Kurset strækker sig i alt over syv uger med undervisning samt tiden efterfølgende til forberedelse og deltagelse i en skriftlig eksamen. Kurset evalueres på baggrund af præstationen til den skriftlige eksamen og opnåede point undervejs i kurset (Bjælde, 2016). Disse point undervejs gives for online-aktiviteter inkl. formidlingsopgaven, som denne artikel omhandler.

Formidlingsopgaven bliver stillet i uge 4 af kurset og forløber over to uger. I den periode arbejder studerende alene eller i grupper af to, tre eller fire. Opgaven består i at søge information og formidle det i form af et produkt. Både målgruppe og valgt medie eller formidlingsmetode for produktet er frit, så længe et produkt kan forelægges. Opgaven rummer dermed en stor åbenhed og kræver stort initiativ og autonomi fra de studerende selv. Som en hjælp bliver et idekatalog vedlagt ved opgavens start.

Formidlingsopgaven blev efter afslutningen på to arbejdsuger bedømt og kunne give op til 100 point. Opgaven vægtede efterfølgende $10 \%$ af den samlede eksamenskarakter i kurset. Ved opgavens start blev følgende bedømmelseskriterier præsenteret, så de studerende kunne tage højde for kriterierne i udarbejdningen af deres formidlingsprodukt.

- Forklaring og inddragelse af fysiske begreber og fysiske hændelser fra Universets historie (20 point)

- Kobling af fysiske koncepter og fysiske hændelser i Universets historie med hinanden (20 point)

- Entydig og forståelig formidling/sprogbrug tilpasset målgruppen (20 point)

- Evidensbaseret formidling - antagelser beskrevet, påstande underbygget ( 20 point) 
- Multimodal formidling (dvs. flere kommunikationskanaler som fx tekst, billeder, lyd, musik, video, fysiske objekter, etc.), hvor alle bidrager til formidlingen (10 point)

- Kreativitet/innovation i formidlingen - ikke reproducere (10 point)

Kursets underviser har en særlig rolle, da han både er involveret i udviklingen af formidlingsopgaven, implementeringen samt den efterfølgende behandling, inkl. denne artikel.

Det underliggende læringsdesign for formidlingsopgaven er definerende for de studerendes arbejdsproces med opgaven og er blevet til ud fra principperne i learning by teaching og inquiry-based learning samt ud fra 5E-modellen og ønsket om at arbejde med kreativitet. Designet har som tidligere nævnt fem faser, hvori underviser og studerende har forskellige roller. Designet er afbilledet og uddybet i figur 1.

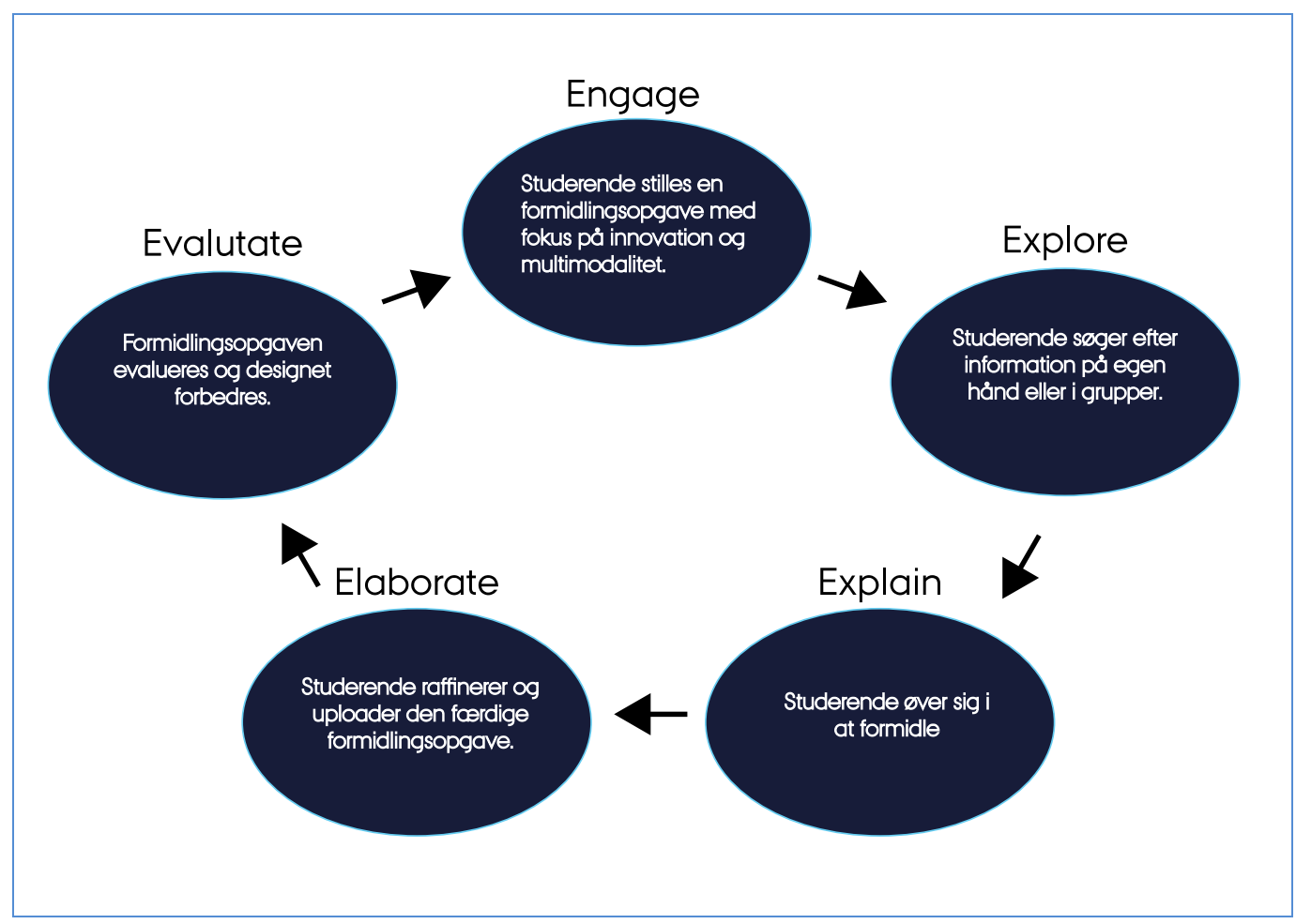

Figur 1: Design for formidlingsopgave i kurset Astrofysik

Engage: Formidlingsopgaven stilles og forklares både skriftligt og mundtligt af underviseren. Der gives bedømmelseskriterier inkl. innovation og multimodalitet samt et inspirationskatalog, men frie rammer for formidlingsopgaven. Studerende læser tekstbog, ser korte videoer om emnet, og går sammen i grupper. Her defineres rammer for projektet som produkttype, målgruppe, faglige spørgsmål - ideelt i et brainstorm-format.

Explore: Studerende arbejder i grupperne med informationssøgning for at finde svar på faglige spørgsmål og med at skabe et overblik over emnet. 
Explain: De studerende skaber deres egen forståelse ved at kommunikere faglige emner. På den måde træner de deres formidlingskompetencer.

Elaborate: Studerende håndterer faglige udfordringer ved at diskutere dem i fællesskab. Studerende udforsker implikationer og sammenhænge mellem koncepter.

Evaluate: Formidlingsopgaven evalueres; både kvalitativ evaluering fra både undervisers og studerendes side samt en kvantitativ pointscoring af de uploadede formidlingsopgaver, som endvidere tæller med i den samlede bedømmelse af kurset. Evalueringen bidrager til at designet for formidlingsopgaven kan forbedres til næste gang, hvilket også er forklaringen på det cykliske design.

Designet og bedømmelseskriterierne er grundlagt ud fra følgende overvejelser:

- Undervisningen skal være studenterfokuseret, hvor den studerende bliver en aktiv deltager og betros selvstændighed i et inquiry-based learning-studieforløb. Ideelt følger studerendes arbejdsproces 5Emodellen således at arbejdsprocessen bliver forskningslignende.

- De studerende skal både lære at formidle, og de skal lære det faglige indhold ved at formidle. Derfor underlægges undervisningsforløbet learning by teaching.

- Da den moderne forsker har mulighed for at anvende talrige formidlingskanaler, er det vigtigt at kunne håndtere formidling igennem flere medier. Formidlingen kan derfor foregå igennem et (eller flere) af disse mange medier. At være fortrolig med dette kan med fordel trænes.

- Kreativitet er træning i at nytænke og ikke reproducere. Dette er en vigtig egenskab bl.a. som forsker.

- Sociale interaktioner kan have stor indflydelse på læring, og der vil derfor lægges op til, at dette inquiry-based learning-forløb foretages i grupper.

- Evalueringen af opgaven sker på baggrund af både faglighed og metoder/kompetencer. Kurset stiller internt krav om faglighed (lærebog og kursuskataloget). Krav om metoder og kompetencer kan findes i forskellige formelle dokumenter (bl.a. studieordningen for uddannelsen).

- Evalueringen af forløbet ved design-based research inddrager blandede typer empiri, der tilsammen skaber en helhedsvurdering, som kan transformere designet.

Som en tilføjelse til disse overvejelser er læringsdesignet ikke skabt med henblik på at løse et problem i det berørte kursus. Hovedfokus er at eksperimentere med nye undervisningsformer og sætte endnu mere fokus på vigtige kompetencer som formidling og kreativitet. Således skal denne publikation også ses som en del i en vidensdeling af netop dette for at inspirere andre undervisere og undervisningsudviklere til at tænke i de samme baner. 


\section{Empiri}

Analysen af de studerendes arbejdsproces og værdien af det underliggende læringsdesign er blevet udført med brug af følgende empiriske materiale, som både inkluderer kvalitativ såvel som kvantitativ empiri.:

- Interviews med tre studerende (Studerende \#1, Studerende \#2 og Studerende \#3)

- Spørgeskemaundersøgelse blandt alle studerende

- Talværdier fra bedømmelse af formidlingsopgaverne

De tre interviewpersoner var alle deltagere på kurset, hvoraf de to var i samme tremandsgruppe og en var i en firemandsgruppe. Interviews blev lavet ud fra en eksplicit spørgeguide, lavet ud fra tre tematiske spørgsmål

- Hvilke metodiske arbejdsmønstre har gjort sig gældende under gruppearbejdet hos de studerende, og hvordan har de struktureret deres arbejdstid?

- Hvordan har self-efficacy haft en indflydelse på de studerende, og hvad har været udfordrende?

- Hvad har de studerende betragtet som frugtbart under arbejdsprocessen, og hvordan betragter de deres eget arbejde? Interviews blev udført semistruktureret, således at interviewsituationen fulgte samtalens udvikling, og der blev, af flere årsager, divergeret en smule fra spørgeguiden undervejs. I analysen bliver citater fra transskriptionerne af interviews inddraget for at besvare problemstillingerne.

Spørgeguiden til de tre interviewpersoner kan findes i Appendiks A.

Alle studerende blev efter aflevering af formidlingsopgaven bedt om at svare på et spørgeskema for på et oplyst grundlag at kunne foretage en fyldestgørende evaluering af hele formidlingsopgaven, inkl. det underliggende læringsdesign. Udformningen af spørgsmålene til spørgeskemaet minder om udformningen af interviewspørgsmålene. Besvarelsesprocenten af spørgesskemaet blev 50,9\% (57 ud af 112 studerende).

Spørgsmål i spørgeskemaundersøgelsen blandt alle studerende kan findes i Appendiks B. Ikke alle disse spørgsmål er relevante for denne publikation. Svar på det mest relevante af disse spørgsmål kan findes i Appendiks C.

Der blev i alt indleveret 44 produkter til bedømmelse lavet af 112 studerende med forskellige gruppestørrelser. Hver gruppe har fået en samlet bedømmelse. Alle produkter er blevet bedømt ud fra de seks bedømmelseskriterier, som er præsenteret tidligere. Point givet under hvert kriterium er tilgængelige for analysen.

\section{Realisering}

I dette afsnit beskriver og analyserer vi resultater samt studerendes og underviserens oplevelse af formidlingsopgaven. Vi lægger særligt fokus på 
effekten af det anvendte læringsdesign ud fra følgende tre forskningsspørgsmål:

- Hvilke metodiske arbejdsmønstre har gjort sig gældende under studerendes arbejde med formidlingsopgaven?

- Hvad har været udfordrende for studerende i forbindelse med arbejdet med formidlingsopgaven?

- Hvad har studerende oplevet som særlig frugbart i forløbet?

Vi analyser og svarer på forskningsspørgsmålene ud fra empirien, som inkluderer følgende talværdier.

- 44 produkter er blevet bedømt i formidlingsopgaven

- 112 studerende har fået et produkt bedømt

- 35 studerende afleverede ikke et produkt til bedømmelse

- 57 studerende har besvaret spørgeskemaet

Fordelingen af point for de studerende, som afleverede et produkt fremgår at Tabel 1. Bemærk at 100 point er det maksimale antal $i$ formidlingsopgaven. Ligeledes fremgår den endelige eksamenskarakter, hvor formidlingsopgaven samlet udgør $10 \%$. Den samlede gennemsnitsscore var 89,8 $\pm 10,5$.

\begin{tabular}{|ccc|}
\hline Karakter & Point & Antal \\
\hline 0 & $82,3 \pm 4,7$ & 3 \\
\hline 2 & 60 & 1 \\
\hline 4 & $86,2 \pm 14,6$ & 17 \\
\hline 7 & $86,7 \pm 16,7$ & 46 \\
\hline 10 & $92,8 \pm 4,7$ & 30 \\
\hline 12 & $96,0 \pm 3,7$ & 12 \\
\hline UB & $88,7 \pm 8,6$ & 3 \\
\hline
\end{tabular}

Tabel 1: Sammenhæng mellem eksamenskarakter og antal point (inkl. standardafvigelser), som de studerendes formidlingsprojekter blev bedømt til. Bemærk at UB betegner studerende Uden Bedømmelse, da de ikke gik til den afsluttende eksamen. Bemærk også at da kun en studerende modtog karakteren 2 til eksamen, kan vi ikke angive en standardafvigelse.

Tabel 1 afslører, at studerende med en høj samlet karakter i kurset også generelt modtog mange point for formidlingsopgaven med en lille spredning. Det er ikke overraskende, særligt da formidlingsopgaven udgør $10 \%$ af den samlede karakter. Mere interessant afslører tabellen, at studerende, som modtog en samlet karakter på 4 eller 7 modtog point med en meget stor spredning. Nogle studerende har således modtaget tæt på det maksimale antal point i formidlingsopgaven, men ikke klaret den samlede bedømmelse på samme niveau. Det tyder på, at formidlingsopgaven belønner andre kompetencer, end dem som honoreres i resten af den samlede bedømmelse. Gode eksempler på det er kompetencer som 
kreativitet og multimodal formidlingsevne, som findes i de to sidste bedømmelseskriterier for formidlingsopgaven. Begge kompetencer har mange studerende mestret, idet mere end halvdelen af de bedømte formidlingsopgaver er blevet belønnet med $10 \mathrm{ud}$ af 10 point for enten kriteriet multimodal formidling eller kriteriet kreativitet. Det kom blandt andet til udtryk i en stor variation i produkttyper, som indeholdt 14 videoproduktioner, 5 interaktive præsentationer, 4 tegneserier, 4 traditionelle dokumenter, 3 filmfortællinger, 2 hjemmesider, 2 sange, 2 nyhedsindslag, 2 børnebøger, 2 facebook-sider, 1 julekalender, 1 kogebog, 1 novelle og 1 toiletrulle.

\section{Arbejdsmønstre}

Med udgangspunkt i de tre interviews kan vi placere studerendes arbejdsproces i de forskellige faser i 5E-modellen. Faserne er i praksis overlappende, især da studerende ikke har været bevidst om disse faser, og processen har i nogle tilfælde bevæget sig frem og tilbage mellem faserne.

Engage: Denne første fase tager til dels sit udgangspunkt i, at opgaveformuleringen stilles på en pirrende måde, der vækker nysgerrighed hos de studerende. I engage-fasen besluttes, hvordan de studerende vil gribe opgaven an, dvs. de vælger målgruppen, typen af produkt og hvilke faglige spørgsmål, de vil beskæftige sig med. Studerende \#1 beskrev: "Vi havde haft en brainstorm til at starte med, hvor vi havde nogle forskellige ideer." Og Studerende \#2 sagde: "Først skrev vi bare en liste op over ting, vi kunne komme ind på i en præsentation. Så måtte vi siden hen nå frem til, at noget var for svært at forklare." En studerende i spørgeskemaerne skrev desuden: "... Vi brugte også en del tid på at diskutere/brainstorme inden vi fandt det endelige format af produktet."

Explore: I Studerende \#1s gruppe havde de besluttet sig for at lave interviews, hvor de i denne fase formulerede spørgsmål, de kunne stille folk på gaden. At stille disse spørgsmål er en del af udforskningen omkring, hvad der er gængse forestillinger om emnet. Dernæst søgte de information, for selv at kunne formulere svar på disse spørgsmål. I Studerende \#2 og \#3s gruppe var explore og explain overlappende, da gruppemedlemmerne delte opgaverne ud, hvor nogen søgte information om dybdegående emner, mens andre begyndte at arbejde på en Prezi-præsentation.

En studerende skrev desuden i spørgeskemaet: "...der var lidt huller i vores viden omkring forskellige ting. Huller som vi måtte udfylde ved at læse på nettet eller læse i bogen." Kommentaren her illustrerer styrken ved explorefasen.

Explain: I Studerende \#1s gruppe havde de uddelt de faglige spørgsmål, så de individuelt kunne besvare dem hjemme. Ligeledes havde Studerende \#2 og \#3s gruppe uddelt en række spørgsmål, som de hver formulerede svar til. I begge tilfælde har der derfor været en fase, hvor den enkelte 
studerende har genereret sin egen forklaring. Som det næste har forklaringerne været diskuteret i gruppen. Det har vi placeret i næste fase, da det er en dybdegående undersøgelse af forklaringerne.

En studerende bemærkede i spørgeskemaet værdien af netop denne fase: "Jeg synes at det giver meget at lære fra sig, og på den måde synes jeg projektet er en rigtig god idé. Man skal sætte sig så godt ind i stoffet at man kan formidle det videre."

Elaborate: At overveje alternative forklaringer tilhører blandt andet denne fase. I praksis fandt dette sted på grund af samarbejdet i gruppen, da de gav respons til hinandens forklaringer. Studerende \#3 sagde i interviewet: "efterhånden som vi skrev, så kom der lidt mere kød på, og det blev lidt mere dybdegående. [...] Og selvfølgelig har vi også læst hinandens igennem og snakket om tingene, så vi er enige om, hvad der står om dem." De brugte på denne måde hinanden i gruppen til at diskutere koncepterne for sammen at nå til enighed omkring, hvordan man skulle forstå fysikken bag. "Det viste sig, at vi ikke havde forstået det så godt, som vi troede. Da vi skulle forklare det for hinanden, viste det sig, at vi havde hver vores forståelse." sagde Studerende \#2. På samme måde beskrev Studerende \#1: "Da vi selv skulle stå og forklare det, diskuterede vi indbyrdes undervejs, hvad der er den rigtige måde at sige det på. Så det var med hinanden, vi sparrede og justerede. Jeg ville ønske, vi havde haft mere tid til den fase. Det ville have været en fordel, tror jeg."

Det tyder på, at elaborate-fasen særligt fremkommer ved, at de studerende lytter til og vurderer hinandens forklaringer. På denne måde skabes åbenhed over for mulighederne for, at andre forklaringer er bedre. Dette giver en mere reflekteret og dybere læring. Den indbyrdes vurdering vil ikke på samme måde være til stede hos de studerende, der arbejder enkeltvis, og kan være en af årsagerne til, at disse studerende har klaret sig mindre godt. Således har 14 studerende, som arbejdede alene en gennemsnitsscore på $81,6 \pm 10,5$ for formidlingsprojektet sammenlignet med en gennemsnitsscore på $90,9 \pm 9,1$ for 98 studerende i grupper, jf. Tabel 2.

\begin{tabular}{|ccc|} 
Gennemsnitsscore & Alene/gruppe & $\begin{array}{c}\text { Antal } \\
\text { studerende }\end{array}$ \\
\hline $\mathbf{8 1 , 6 \pm 1 0 , 5}$ & Alene & 14 \\
\hline $\mathbf{9 0 , 9 \pm 9 , 1}$ & Gruppe & 98 \\
\hline
\end{tabular}

Tabel 2: Gennemsnitsscore vs. alene/gruppe-arbejde i formidlingsopgaven.

Yderst til højre antallet af studerende, som arbejdede hhv. alene og i grupper.

Evaluate: I denne fase begrænses de studerendes arbejde til udfylde et spørgeskema, hvor de reflekterer over udbyttet af formidlingsopgaven. 
Desuden modtager de respons og point for deres produkter. En analyse og forbedring af designet for formidlingsopgaven finder desuden sted i denne fase.

Overordnet indikerer interviews med de tre studerende og enkelte kommentarer fra spørgeskemaundersøgelsen, at studerendes arbejdsproces i konteksten for dette læringsdesign involverer en række adskilte faser, som til dels overlapper, og som følger 5E-modellen.

\section{Udfordringer}

I løbet af arbejdsprocessen er de studerende stødt på en række forskellige udfordringer, både hensigtsmæssige og hæmmende. Dette afsnit beskriver hvad de studerende, ifølge dem selv, er blevet mest udfordret af.

Spørgsmålet om, hvad der har været den største udfordring for de studerende er blevet stillet direkte i både spørgeskemaet og interviewene, hvilket i begge tilfælde har givet brugbar kvalitativ information. Vi har kodet besvarelserne i følgende kategorier (frasorteret svar fra studerende i kategorier med 5 eller færre): Formidling (14), Teknikken (12), Niveau vs. Målgruppe (9), Komme i gang (9), Valg af information (6), Kreativitet (6). Se den samlede besvarelse af spørgsmålet i spørgeskemaet i Appendiks C.

- Formidling: Udfordringen, at det var svært at forklare stoffet, er en naturlig del af forberedelsesfasen i Learning by teaching. Der kræves, at man omsætter den lærte viden til sin egen forklaring, som Studerende \#1 giver udtryk for: "Det er svært at forklare de her relativt abstrakte koncepter. [...] Jeg tror, den sværeste udfordring var at skulle formidle det med egne ord." En studerende, der har været med til at indspille en film, skrev i spørgeskemaet: "Det er svært at formidle det, man ønsker på den rette måde i et medie, der fastholder ens ord fuldstændigt. " Denne studerende bemærkede dermed, at når forklaringerne filmes og gengives på så eksakt samme måde, har det stor betydning, hvor gode, forklaringerne er: Det bliver tydeligere, hvis forklaringerne kan forbedres.

- Teknikken: En del af kræfterne til opgaven gik til praktiske, tekniske og strukturelle udfordringer, som er nødvendigt for at fuldføre opgaven. Nogle udfordringer var særligt knyttet til det valgte produkt, som fx indspilning og redigering af en film, at få et program til at virke eller at uploade opgaven.

- Niveau vs. målgruppe: Dette punkt beskriver vanskeligheden ved kompromiset mellem at formidle på et niveau, som målgruppen kan forstå, samtidig med, at de studerende kan vise et højt fagligt niveau inden for fysik. En studerende oplevede, at fokus på målgruppen gik ud over produktets taksonomi: "Da vi har valgt en populærvidenskabelig målgruppe, slap vi for at bruge formler, og vores tekst endte med at føles som en meget lang redegørende tekst med lidt fra bogen og lidt fra nettet hist of her." En anden studerende skrev i spørgeskemaet: "Hvis vi skulle kunne opfylde de faglige krav for fysikken, blev man nødt til at vælge ens målgruppe til at være 
universitetsstuderende - da meget stof allerede er for svært for gymnasieelever."

- Komme i gang: Flere studerende har i spørgeskemaet givet udtryk for uoverskueligheden ved opgavens autonomi, eksempelvis denne: "Den var svær at komme i gang med, og det var svært at finde målgruppen. Men opgaven i sig selv var meget åben, og det var lige netop, hvad der gjorde den svær."

- Kreativitet: Autonomi udfordrer de studerendes kreative evner, hvilket vil sige de studerendes evne til at nytænke. Ifølge dem selv havde de studerende svært ved at være kreative. En studerende skrev i spørgeskemaet: "Det var meget svært at komme i gang, fordi ingen $i$ vores gruppe er vildt kreative så man kan hurtigt komme til at sidde og hænge uden at komme nogen steder." Og en anden studerende skrev: "Det var lidt stressende, at kreativitet var et mål i sig selv." Og en tredje skrev: "Denne slags opgaver er bestemt en gave til kreative folk, som godt kan lide at arbejde alternativt/anderledes med stoffet. Men for mig var det mest af alt en belastning."

De studerende har således, under forløbet, mødt en række udfordringer. Flere af disse er hensigtsmæssige processuelle udfordringer. Selve den faglige udfordring ved at sætte sig ind i et nyt emne og forstå de fysiske koncepter er ikke så fremtrædende i de studerendes formuleringer, men kommer alligevel indirekte til udtryk ved, at mange studerende oplever, at det er svært at forklare koncepterne. Dette er forklaringsfasen i Learning by teaching tilgangen, hvor de studerende skal anvende den viden, de har tilegnet sig. I den anledning bliver det tydeliggjort, hvis de ikke har forstået den information, de har søgt.

Mange af de studerende har haft svært ved at håndtere opgavens åbenhed. Dette er en nødvendig del af den kreative proces, hvilket er en udfordring, de studerende ikke er vant til at håndtere. Selvom det er en vigtig del af forløbets udfordring, at der stilles en meget åben opgave, kan opgaven virke abstrakt i starten af processen, og mange har svært ved at komme i gang. For at tage hensyn til self-efficacy er det hensigtsmæssigt, at den oprindelige opgaveformulering er så klar som muligt, så de studerende forventer at kunne mestre opgaven.

Da mange studerende ikke betragter sig selv som kreative, er der to måder at håndtere dette på i den tidlige del af forløbet: Den ene måde er, at formuleringer af intentionen om, at det skal være en kreativ opgave, ikke fremstår som et hovedfokus, men snarere det faglige. Den anden måde er at overbevise de studerende om, at enhver har evnerne til at være kreativ, da det handler om at tænke selvstændigt. Sidstnævnte kan have positiv indflydelse på self-efficacy.

\section{Frugtbare elementer}


I interviews og spørgeskemaet har de studerende knyttet mange positive kommentarer til forløbet. En studerende sagde: "Min første tanke var - det er ligegyldigt kedeligt, det gider jeg ikke. Hvad skal jeg bruge det til? Men efterhånden har jeg ændret mening 180 grader - for formidling er noget, man fär brug for senere, UANSET hvad den mere specifikke uddannelse bliver." Denne studerende fremhæver altså fordelen ved at blive bedre til at formidle, da det kan bruges professionelt. Studerende \#2 anerkender også dette: "At formidle fysik er en god egenskab at have, som der ellers ikke lægges så meget vægt på."

En anden studerende sagde: "Jeg synes, at det giver meget at lære fra sig, og på den måde synes jeg, projektet er en rigtig god idé. Man skal sætte sig så godt ind i stoffet, at man kan formidle det videre." Denne studerende fremhæver læringspotentialet ved at skulle forklare den tilegnede viden. Om dette sagde Studerende \#3 også: "Jeg synes faktisk, jeg lærte en del under dette her projekt. At skulle sidde og skrive det ned og forklare det. Så er man virkelig nødt til at forstå det." Dette er en af fordelene ved Learning by teaching læringsstrategien.

Sidstnævnte studerende fra spørgeskemaet sagde fortsat "At det skulle præsenteres i et frit medie virkede forresten helt fint. Vi valgte at lave en hjemmeside, og det gjorde det lidt sjovere, end hvis det var et Word dokument." En tredje studerende sagde: "Generelt synes jeg, at projektet var en god idé. Det er en god afveksling fra den normale måde at studere på, hvor man læser tingene, hører forelæsninger, laver opgaver og gennemgår opgaver. Den kreative udfordring er en god opkvikker fra den ellers rimeligt monotone studiegang. Det fremprovokerer også selvstændighed, da der ikke er specifikke opgaver, som man skal lave. Interessen hives derved også frem."

Den studerende fremhæver, at opgaven fremprovokerer selvstændighed, som giver et positivt motivationsbidrag. Studerende \#3 sagde desuden: "Nu havde jeg også et par punkter, hvor jeg i dybden skulle beskrive fysisk, hvad der skete her. Det var jeg ret glad for, og jeg følte også, at jeg lærte noget." Studerende \#3 oplevede altså denne selvstændige fordybelsesproces som udbytterig.

Samlet set er der altså flere af de studerende, der anerkender fordele ved formidling på to måder: At det er en god kompetence at opbygge, og at det i sig selv er lærerigt ved, at det udfordrer den faglige kunnen. Mange studerende har været motiveret af forløbet, fordi de får lov til at vise selvstændighed, hvilket stemmer overens med ønsket om forskningslignende undervisning.

\section{Perspektivering og diskussion}

Studerendes arbejde med formidlingsopgaven har, samlet set, haft en række muligheder og udfordringer. Læringsdesignets udfordringer skal så 
vidt muligt håndteres, når designet justeres til næste iteration. Den første version af læringsdesignet har en meget åben opgaveformulering, hvilket overlader en stor grad af autonomi til de studerende. Det kan potentielt true deres oplevelse af at være kompetente, og dermed påvirkes deres selfefficacy (Krogh \& Andersen 2013).

De studerende giver udtryk for, at de har mødt mange udfordringer undervejs, men mange af disse udfordringer er hensigtsmæssige. I forhold til de studerendes motivation har det vist sig, at et flertal jf. spørgeskemaet er åbne for at opleve et lignende undervisningsforløb blive gentaget. Det fremgik også, at de studerende har scoret mange points for deres formidlingsprodukter, og flere af de studerende, der fik en lavere en middelkarakter til eksamen, formåede at fremstille produkter med en høj score (se tabel 1). Det vil sige, at der blandt andet er en gruppe studerende, der under den konventionelle eksamensform kan præstere til en lav karakter, men som formår at formidle fysik og skabe kreative produkter til en meget højere bedømmelse. Ud fra dette kan det diskuteres, om de konventionelle eksamensformer egner sig til at evaluere studieordningens kompetenceprofil, eller om der kun testes en lille del af den samlede kompetenceprofil. Mere dybdegående diskussioner om universitetsinstitutionens eksamensformer ligger dog uden for denne artikels omfang.

Det tyder på, at på trods af de mange udfordringer, samt autonomiens store indflydelse på self-efficacy, har de studerende overordnet kunnet håndtere opgavens åbenhed. Det kan måske skyldes, at vi godt kan forlange selvstændighed af nye universitetsstuderende. Det er i overensstemmelse med, at overgangen fra gymnasieskolen til universitetsinstitutionen også er en overgang til forskningsbaseret undervisning, som på flere måder ideelt bør rette et stort fokus mod selvstændighed og studenterfokuseret undervisning. At studerende har kunnet magte opgaven, ses blandt andet ved at de studerende i gennemsnit $89,8 \pm 10,5$ points for opgaven ud af 100 mulige point. Overordnet har det altså vist sig, at de studerende i høj grad har imødekommet kriterierne tilfredsstillende.

Der har vist sig en tendens til, at studerende, der har arbejdet individuelt, har fået færre point for formidlingsopgaven end studerende i grupper. Dette kan være relateret til, at samarbejdet i gruppen har en række frugtbare bidrag, eksempelvis at alle har et fælles ansvar for at yde en indsats med opgaven. Særligt elaborate-fasen er afhængig af, at man indgår i et samarbejde, så de studerende kan give hinanden respons. Netop i denne fase revurderes forklaringer, hvilket kan give refleksioner, der fører til en dybere læring. Det er derfor muligt, at hvis flere studerende opmuntres til at indgå i gruppearbejde, kan det øge deres indsats i forløbet, og enkelte studerende, der i dette forløb har scoret få points, ville kunne 
forbedre deres indsats.

For at imødegå udfordringen med self-efficacy vil studerende fremover møde eksempler fra dette første forløb på succesfulde produkter, så de har retningslinjer og inspiration til opgaven. Et problem ved dette valg kan dog være, at de kan frarøves mulighederne for at fremstille lignende produkter, da det kan komme til at fremstå reproducerende og mangle kreativitet. En måde at løse problemet på kan være, at der inkluderes flere emner i formidlingsopgaven, så designet testes i nye sammenhænge. På den måde kan de studerende få nye chancer for at tænke kreativt, og visse af de tidligere formidlingsprodukter kan måske endda anvendes i undervisningen, så flere faglige fokusområder dækkes med kreative undervisningsmaterialer, der autentisk er fremstillet af andre studerende. Disse tiltag forventes at have en positiv effekt på studerendes self-efficacy.

Det har vist sig, at studerende, mere eller mindre, har påtaget sig faserne i 5E-modellen ubevidst, hvilket understreger læringsdesignets styrke og fordelen ved en arbejdsstruktur af dette format. Inquiry-based learning kan derfor godt fungere under relativt frie rammer, hvor de studerende får mulighed for at udvise selvstændighed. Andre undervisere kan med fordel anvende samme design, idet der ikke er noget emneafhængigt indbygget $\mathrm{i}$ designet. Designet sikrer, at studerende øver sig i formidling, kreativitet og informationssøgning. Desuden giver det anledning til frugtbare elementer af samarbejde, og man kunne overveje at gøre samarbejde obligatorisk i designet.

Der er ikke i designet direkte indbygget, at det henvender sig til universitetsstuderende. Dette design er ganske vist udformet ud fra et ønske om i højere grad at leve op til kvalifikationsramme og bekendtgørelse for universitetsuddannelser, men eksempelvis formidling er også en del af bekendtgørelsen inden for mange fag i gymnasieskolen. Således vil designet også kunne anvendes i en gymnasiesammenhæng.

Foruden det positive læringsbidrag hos de studerende, har formidlingsopgaven også efterladt 44 gennemarbejdede formidlingsprodukter. Disses påvirkning kan strække sig ud over kursets rammer og give et læringspotentiale i bredere forstand. Det har vist sig, at mange har vist interesse for nogle af de mest succesfulde produkter, og formidlingen er nået et meget bredt publikum. Via venner, bekendte og familiemedlemmer til studerende er produkterne nået ud til mange mennesker. Ligeledes har mange andre studerende, gymnasielærere og almindelige mennesker vist stor interesse for særligt innovative produkter via fakultetets Facebook-side (Facebook, 2016). Underviseren har også selv anvendt enkelte af formidlingsopgaverne i populærvidenskabelige og rekrutteringsmæssige sammenhænge. 


\section{Konklusion}

Formidling er en central kompetence at lære af flere årsager. Når de studerende afslutter studiet vil de, der har interesse i at undervise, finde anvendelse i dette, men også forskeren har brug for denne kompetence. Forskningsbaseret undervisning stræber efter at skabe en nær sammenhæng mellem forskning og undervisning på flere planer, og universitetsinstitutionen har også et ansvar for at formidle naturvidenskab for den brede befolkning. Derfor er det vigtigt, at de studerende tidligt lærer at formidle til flere målgrupper. Ud over dette giver Learning by teaching mulighed for et stort læringsbidrag, hvor dyb læring kan finde sted. Kreativitet udfordrer evnen til at være nytænkende, som også er en eftertragtet egenskab.

Med fokus på disse elementer har vi udformet et læringsdesign for kurset Astrofysik og undersøgt værdien af designet med kvantitativ og kvalitativ empiri i en design-based research-metode. 112 studerende har i dette undervisningsforløb fremstillet 44 formidlingsprodukter, der omhandler Universets historie fra Big Bang til i dag. Med fokus på forskningsspørgsmålene kan vi på baggrund af empiri, analyse og diskussion konkludere, at vi har skabt et undervisningsforløb, som i høj grad intervenerer i undervisningspraksis, som får studerende til at nytænke og være kreative, og som træner formidlings-kompetence på en hensigtsmæssig og succesfuld måde. Det er således sammenhæng mellem intention, implementering og realisering af det underliggende læringsdesign. Jf. design-based research-metoden vil læringsdesignet ydermere løbende blive forbedret og tilpasset, og det er vores håb, at dette forløb i fremtiden kan inspirere andre undervisere til i højere grad at skabe studenterfokuseret undervisning, så der fås færdiguddannede kreative, selvstændige og formidlingskompetente kandidater, der har oplevet tydelig forskningsbaseret undervisning.

\section{Acknowledgements}

OEB takker Mikkel Godsk for diskussioner om læringsdesign, Birgitte Lund Nielsen for inspiration, feedback og diskussioner om design-based research samt Lars Kruse for at tage billedet på forsiden af artiklen.

\section{Referencer}

Amiel, T., \& Reeves, T. (2008). Designbased research and Educational Technology: Rethinking Technology and the Research Agenda. Educational Technology \& Society, No. 11.

Badley, G. (2002). A really useful link between teaching and research, Teaching in Higher Education, 7(4): 443-55. 
Bandura, A. (1977). Self-efficacy: Toward a unifying theory of behavioral change. Psychological Review, Vol 84(2), 191-215.

Bjælde, O. E. (2016). Kursuskataloget på Aarhus Universitet: http://kursuskatalog.au.dk/da/(5/9 2016).

Brun, T., Gynther, K., \& Christensen, O. (2012). Design-Based Research introduktion til en forskningsmetode i udviklingen af nye Elæringskoncepter og didaktiske design medieret af digitale teknologier. Læring og medier, Årgang 5(9), 1-20.

Bybee, R. W. (2014). The BSCS 5E Instructional Model: Personal reflections and contemporary implications, Science and Children, Bind 51, Hæfte 8, Side 10-13.

Carless, D. (2015). Excellence in University Assessment. Routledge, New York, New York, USA.

Cobb, P., Confrey, J., diSessa, A., Lehrer, R., Schauble, L. (2003). Design experiments in educational research. Educational Researcher, 32, 1: 9 13.

Conole, G. (2013). Designing for Learning in an Open World. New York, New York, Springer, USA.

Dalziel, J., Conole, G., Wills, S., Walker, S., Bennett, S., Dobozy, E., Cameron, L., Badilescu-Buga, E., Bower, M. (2013). The Larnaca Declaration on Learning Design: http://www.larnacadeclaration.org/ (21/11 2016).

Det Danske Sprog- og Litteraturselskab: http://ordnet.dk/ddo/ordbog?query=kreativitet (5/9 2016).

Drapeau, P. (2014). Practical Ways to Promote Innovative Thinking and Problem Solving. ASCD, Alexandria, Virginia, USA.

Eksamensbekendtgørelsen (2016). Uddannelses- og Forskningsministeriet. Udskriftsdato: 22. august 2016.

Facebook (2016). https://www.facebook.com/scitech.au (7/9 2016).

Healey, M. (2005). Linking research and teaching exploring disciplinary spaces and the role of inquiry-based learning, in Barnett, R (ed) Reshaping the university: new relationships between research, scholarship and teaching McGraw-Hill/Open University Press, 67-78.

Krogh, L. B. \& Andersen, H. M. (2013). Elevers motivation i undervisningen, I Damberg et al., Gymnasiepædagogik, 2. udgave, 2. oplag, Hans Reitzels forlag, København, Danmark.

Martin, J.-P. \& Kelchner, R. (1998): „Lernen durch Lehren“. In: Timm, J.-P. (Hg.): Englisch lernen und lehren - Didaktik des Englischunterrichts. Berlin: Cornelsen, 211-219. 
Martin, Jean-Pol (2004) "Lernen durch Lehren: quand les apprenants font la classe", Recherche et pratiques pédagogiques en langues de spécialité - Cahiers de l APLIUT, Hæfte Vol. XXIII 1, 45-56.

Najbjerg, R. B. (2016). Kreativt formidlingsprojekt som læringsstrategi: En design-based research undersøgelse af kurset Astrofysik (Ikke-publiceret speciale i fysik). Aarhus Universitet, Aarhus, Danmark.

Rienecker, L., Jørgensen, P. S., Dolin, J. \& Ingerslev, G. H. (2013). Universitetspædagogik, 1. udgave, Samfundslitteratur, Frederiksberg C, Danmark.

Semke, A. \& Wiben, H. (2016), Personlige kompetencer i EUD, 1. udgave, Munksgaard, København, Danmark.

Thomson, P. \& Sefton-Green, J. (2011). Researching Creative Learning: Methods and issues, 1. udgave, Routledge, Abingdon, Oxon, England.

Uddannelsesbekendtgørelsen (2016). Uddannelses- og Forskningsministeriet. Udskriftsdato: 7. juli 2016. 


\section{Appendiks A}

Her spørgeguiden i sin helhed, som blev brugt under interviews med tre studerende. Interviews blev udført af Rasmus B. Najbjerg.

1) Hvordan gik det med at komme i gang med opgaven?

2) Hvordan var det at have så frie rammer?

3) Hvad inspirerede jer til at vælge den type opgave, som I gjorde?

4) Hvordan bar I jer ad med at søge brugbar information?

5) Hvordan fordelte I arbejdet imellem jer i gruppen?

6) Oplevede du det som udfordrende at forklare koncepterne?

7) Hvordan havde I det med at ramme målgruppen?

8) Ændrede I jeres fokus undervejs ved fx at komme på nye ideer eller fjerne ideer?

9) Hvad var den største udfordring undervejs?

10) Synes du, det var en svær opgave?

a. Hvad var med til at gøre det svært/let/medium?

11) Oplevede du selv det endelige produkt som en succes?

a. Også i forhold til målgruppen?

12) Kan du vurdere, hvor længe, I samlet har brugt på dette forløb?

13) Har det været lærerigt?

14) Hvad synes du om forløbet i forhold til den normale undervisning?

15) Ville du synes om at opleve et lignende projekt i et senere universitetskursus?

\section{Appendiks B}

Her spørgeskemaet i sin helhed, som blev givet til alle studerende.

1) Hvor mange personer er i din gruppe? [1, 2, 3, 4]

2) Hvilken type produkt har du/I valgt? (Multimediepræsentation, tegneserie, nyhedsindslag, portal til surfing, YouTube-video, udstilling, andet (skriv)) [fri tekst]

3) Hvilken målgruppe har du/I valgt? (Folkeskole, gymnasie, medstuderende, den almene borger der selv har opsøgt viden af interesse, den almene borger der ikke har en forudgående interesse for emnet, anden målgruppe (skriv)) [fri tekst]

4) Hvilke informationskilder brugte du/I til at søge information? Afkryds alle, som passer. [Lærebogen, kursets online-videoer, NASA's arkiver, ESA's arkiver, HubbleSite, ScienceDaily, Khan Academy, Sean Carrolls blog, andet]

5) Hvis du skrev andet ovenfor, så uddyb hvilke informationskilder i tekstfeltet her. [fri tekst]

6) Hvad var den største udfordring undervejs? [fri tekst]

7) Hvilke af følgende beskrivelser synes du passer godt på din oplevelse af arbejdsprocessen? (kryds flere af) [motiverende, spændende, kompetencebyggende, lærerigt, åbner mange muligheder, har hjulpet til at tænke kreativt, afvekslende, ligetil, udfordrende, nemt, lige så godt eller bedre end normal undervisning, mindre godt end normal undervisning, var for ukonkret, forvirrende, frustrerende, spild af tid, demotiverende, stressende, svært at komme i gang] 
8) I hvor høj grad betragter du det endelige produkt som en succes? [I høj grad, i nogen grad, hverken eller, slet ikke]

9) Hvor mange timer har du omtrent samlet brugt på formidlingsopgaven? [5- 10, 10-15,15-20,20-25, mere end 25]

10) Ville du synes om at opleve et lignende projekt i et senere universitetskursus? [Ja gerne, ja undtagelsesvist, ved ikke, helst ikke, slet ikke]

11) Har du yderligere kommentarer [fri tekst]

\section{Appendiks C}

Den samlede liste af svar på spørgsmål 6 i spørgeskemaet: Hvad var den største udfordring undervejs?

- $\quad$ "At finde ud af hvor svært fagligt det skulle laves. Sådan at den almene befolkning kunne forstå det, men uden at miste for mange fagord."

- "At få struktur på opgaven og få formidlingen til at passe med målgruppen"

- " "Formullere sig orentligt og vaelge relevant information."

- "At finde på en god måde at fremvise det på."

- " "Tror ikke der var så mange udfordringer ."

- "At finde på en idé til hvilket produkt vi skulle lave."

- "Den største udfordring var for mig helt klart ikke at kopierer og tale for meget ud fra bogen. Dette følte jeg ikke, at jeg klarede tilfredsstillende. "

- "At sørge for at formidlingen passede målgruppen. Altså at det ikke var for nemt eller for svært stof der blev gennemgået."

- $\quad$ "At finde en passende formidlings form, der kunne rumme alle de kriterier som opgaven blev bedømt på."

- "Valg af målgruppe og faglighed kontra formidling."

- "At finde gode animationer som k unne illustrere, hvad vi ønskede at vise eleverne."

- "At være kreativ"

- "Kreativitet"

- $\quad$ Har aldrig lavet en tegneserie før , at omsætte ens ideer til en let læselig kort tegneserie var mere tidskrævende end jeg troede."

- "Vurdering af væsentlig - uvæsentlig"

- $\quad$ "Synes det var svært at opfylde alle kriterierne samtidig. Fx at lave evidensbaseret undervisning når vi har valgt at lave det for en gymnasieklasse (i mit hoved er evidensbaseret undervisning meget med videnskabelige artikler, hvilket jeg ikke synes passer ind med det andet)."

- "At tage sig sammen til at lave noget."

- "At formå at finde en målgruppe men samtidigt at kunne formidle det på et højt fagligt niveau (det blev enten for let i forhold til fagmålene eller for svært for målgruppen)"

- "Komme i gang/ finde det rigtige produkt."

- "At få det vi gerne ville formidle til at passe på det valgte medieformat."

- $\quad$ "At finde tid til at mødes i gruppen og arbejde på projektet. Ellers, at sørge for at få formidlet stoffet letforståeligt til målgruppen , når 
emnet på mange måder er ret abstrakt og hverdagsfjernt. Vi brugte også en del tid på at diskutere/brainstorme inden vi fandt det endelige format af produktet."

- $\quad$ "At vide præcis hvad vi skulle skrive for at falde inden for målgruppen , uden at det blev for teknisk eller for let."

- " "Finde korrekte animationer mv."

- "At få den Interaktiv Power Point at på et ordenligt niveau."

- $\quad$ Forventningsafstemning ift. det afsluttende produkt. Desuden var det lidt svært at afgøre produktets omfang ; hvor meget der skulle med, for at det faglige var tilstrækkeligt. Men det skyldes jo blot opgavens åbenhed."

- "Teknikken."

- $\quad$ "At finde en måde at formulere opgaven samt at finde målgruppen . At finde ud af hvor meget teori der skulle indgå i opgaven . At bedømme mængden af tekst på hvert slide og lign."

- "Idegenereringsfasen"

- "Den største udfording var at vi endte med at have et alt for stort projekt som var for tidskrævende for at kunne gøre det rigtig godt . Vi skulle have indsnævret emnerne endnu mere end vi gjorde."

- $\quad$ "Idegenerering, og derefter strukturering af produktet. Det var svært at finde på en ny formidlingsmåde, og derefter at finde på en måde at strukturere det, så det opfyldte opgavekravene men også produktets form."

- $\quad$ "At få en god idé . Det var lidt stressende, at kreativiteten var et mål i sig selv."

- "At få et flot layout i latex"

- "At finde ud af hvor meget jeg kunne gå i dybten med emnet uden at det ville blive for svært for den almene person at forstå"

- "Det virker svært at opfylde kriterierne for opgaven når man laver en tegneserie til folkeskoleelever ."

- $\quad$ "Den største udfordring var indspilning og redigering af vores film. Der blev brugt meget tid og mange kræfter på at få tegnet tegningerne på den helt rigtige måde , så man bedst kan formidle stoffet.

Herudover tog det også meget tid at få indspillet vores manuskript uden fejl og i det rigtige tempo."

- $\quad$ "Det har været en stor lidt uoverskuel opgave, som samtidig er faldet sammen med en lab rapport. Så at få tid til det hele har været svært."

- $\quad$ "At skabe et overordnet overblik over Universets historie fra det meget tidlige univers til universet i dag og forstå disse perioder, samt at acceptere at meget teori er spekulativt. Desuden var det svært at lave noget spændende visuelt for flere af de tidlige epoker i Universet."

- "Den største udfordring, var at afgrænse os både til et emne, og en udtryksform, idet at det var en meget bred formuleret opgave .

Udover det var der også en række teksniske vanskeligheder med selve produktet."

- "At man skulle bruge så meget tid på det"

- $\quad$ "Det var en meget fri opgave, og det er jo meget fint. Men vi ville jo ogsp gerne gøre dig glad, og det var lidt svært at finde ud af , hvordan vi bedst gjorde det."

- " "At finde ud af, hvordan tingene skulle fremstilles." 
- $\quad$ "At finde ud af hvordan man forklarede elementer af universets historie gennem animationer."

- "At være kreativ"

- $\quad$ "Det er svært at opfylde alle krav, der er blevet opstillet, og samtidig ramme ens målgruppe. Hvordan skal jeg være faglig relevant og forklare astrofysik for en børnehaveklasse eksempelvis?"

- "Forstå præcis hvordan universets udvikling foregik."

- " "At anskaffe et lokale til at optage i."

- " "Indspilning af videoer! Det er svært at formidle det man ønsker og på den rette måde i et medie der fastholder en ord fuldstændigt."

- $\quad$ "To explain the subject somewhat well, with short texts, and only 3 min video"

- " "Finde ud af hvordan man ville formidle stoffet."

- "Formatet var lidt udfordrene, sigesom selve simplifikationen af det svære stof til målgruppen var udfordrene."

- $\quad$ "Finde ud af hvordan det skulle præsenteres. Kreativitet er hverken min eller min makkers stærke side. Desuden, at få det formidlet korrekt"

- $\quad$ "At få uploadet opgaven. Udover det så var det niveauet - for mig fungerede det lidt som en gynge. Jeg vidste jeg kan komme op og ligge næsten vandret, jeg er bare bange for at passagererne tabes undervejs."

- "At tage sig sammen til at komme i gang med opgaven"

- "Finde på hvordan man skulle fremlægge sit projekt"

- " "At finde ud af hvordan man skulle angribe opgaven." 